\title{
Эпоха деятельности профессора Анджея Ситарского - расцвет познанской украинистики (воспоминание-посвящение как эго-текст)
}

\author{
The epoch of the activity of Professor Andrzej Sitarski - \\ the heyday of Poznań Ukrainian studies \\ (a memoir-dedication as an ego-text)
}

\begin{abstract}
The paper is devoted to a holistic analysis of the scientific-organisational and scientific-didactic activity of the Head of the Institute of Russian and Ukrainian philology, Professor Andrzej Sitarski (2008-2019). In the paper, the author presents her reflections on the status of ego-texts along with their categories. The author's attention is primarily focused on the evaluation of Professor Sitarski's role in the upbringing of talented linguists, as well as on his personal contribution to the development of Poznań Ukrainian studies. The in-depth analysis is conducted on the basis of the category of memory that is depicted in ego-text genres, including the genre of memoirs-dedications. Professor Sitarski has an outstanding linguistic personality of a bilingual that boils down to particular verbal and nonverbal properties represented through his psychotype - his abilities of the elite linguistic character of a scientist and lecturer of Russian language are distinctive for him.
\end{abstract}

Keywords: ego-text, the genre of memoirs-dedications, the category of memory, the activity of the Head of the Institute, the elite linguistic character of a scientist and lecturer of Russian language

Tetyana Kosmeda, Uniwersytet im. Adama Mickiewicza w Poznaniu, Poznań - Polska, tkosmeda@ gmail.com, ORCID ID: https://orcid.org/0000-0001-8912-2888

Посвящаю эту статью профессору Анджею Ситарскому в знак глу-

бокого уважения и признательности за долгие и плодотворные годы сотрудничества во имя развития Кафедры украинистики. С наилучшими пожеланиями успехов в дальнейшей научной и педагогической деятельности, радости от искрящейся жизни, доброго здоровья, большого счастья, необыкновенных и увлекательных путешествий, удивительных открытий и непредсказуемых сюрпризов. 


\section{Введение}

Общение - удивительная человеческая способность, составляющая компонент человеческого счастья, имеющая разные формы и виды. На жизненном пути каждого человека встречается множество людей. С некоторыми мы быстро и легко вступаем в коммуникативный контакт, чувствуем гармонию в общении, непринужденность, взаимопонимание, поскольку во время общения возникает то, что объединяет и делает отношения благоприятными, добрыми: это и одинаковое видение мира, его тождественное ощущение, и профессиональные интересы, понимание перспективы сотрудничества, взгляды на актуальные проблемы окружающей действительности и под. Между людьми складываются стабильные и длительные отношения либо кратковременные и не перерастающие в многолетние контакты из-за совокупности факторов и субъективного, и объективного характера. Но человек всегда получает радость от общения в том случае, если Судьба сводит его с уникальными личностями - на длительные годы или на краткие мгновения быстротекущей обыденной жизни, на профессиональной ниве и исключительно в личностных взаимодействиях.

В 2011 году на своем жизненном пути я встретила профессора Анджея Ситарского, пригласившего меня на работу в качестве заведующего Кафедрой украинистики Института русской филологии УАМ. Господин Ситарский нашел нужные слова, аргументы и убедил меня принять его предложение для создания познанской украинистики практически с нуля, поскольку украинский язык в то время изучался лишь как второй язык на русско-украинском отделении. Я предполагала, что пребывание в Институте будет кратковременным периодом моей жизни, но оказалось, что в УАМ я проработала довольно долго - 10 лет.

В канун важной даты - 70-летнего юбилея профессора Анджея Ситарского - в сборнике, посвященном этому событию, как представляется, будет уместной статья, представленная в виде жанра воспоминания-посвящения о деятельности Профессора. Имею возможность привлечь для анализа и эго-тексты профессора Ситарского (Sitarski 2011, 2012), его воспоминания, оценки и размышления.

\section{Воспоминания-посвящения в ракурсе юбилейных эго-текстов}

Жанр воспоминаний, как представляется, сегодня обретает развитие, проектируясь в виде гибридных поджанров: воспоминания-посвящения, воспоминания-рецензии, воспоминания-обзоры и др. о жизни и деятель- 
ности известных людей. Юбилеям видных ученых, преподавателей, организаторов науки посвящаются сборники научных статей, монографии, в многоаспектном фокусе которых отдельная личность - персона, в том числе и языковая. Подобные исследования выполняются и в ракурсе теории лингвоперсонологии, и в аспектах эго-лингвистики, или Я-лингвистики. Материалом для подобных публикаций являются, кроме личных воспоминаний или воспоминаний других лингвоперсон (коллег, соратников, учеников, родственников и под.), документальные факты, тексты автобиографий, письма, дискурс, представляющий творческое наследие лингвоперсоны, и под. Такие эго-тексты преимущественно реализуются в виде комплиментарных, интимизированных, оценочно выраженных авторских размышлений.

В начале XXI века ученые-лингвисты довольно часто создают научные или научно-популярные, публицистические опусы по поводу важных событий, происходящих в жизни их коллег. Иллюстрацией сказанного может быть, например, сборник статей в честь юбилея Нины Давидовны Арутюновой под названием Сокровенныле смысль. Слово. Текст. Культура (2004), в структуре которого имеется статья Сергея Крылова О научном творчестве Н. Д Арутюновой, где автор эмоционально, с восхищением и преклонением предлагает и такой фрагмент интимизированного текста:

Нина Давидовна - не просто блистательный ученый, но и удивительная личность. В ней гармонично соединяются глубокая поглощенность любимым делом и исключительно доброжелательное отношение к окружающим, предельная скромность и неизменное собственное достоинство, чувство юмора и глубина философского проникновения в суть дела. Она, как никто другой, умеет абстрагироваться от всего суетного и второстепенного (в языке, в науке, в жизни), концентрирует внимание на сущностных аспектах и при этом никогда не теряет из виду зримую поверхность живого языка (Krylov 845).

В качестве примера можно привести и книгу с „говорящим названием” Язык. Личность. Текст (сборник статей к 70-летию Татьяны Михайловньл Николаевой) (2005), где помещена статья Владимира Успенского Татьяна Михайловна Николаева как собеседник (Uspenskij). Успенский освещает специфику языковой личности этой ученой в виде воспоминаний-эссе о ее коммуникативной компетентности, манере общаться, вести диалог, умение слушать, моделировать речевые жанры и под. Интерес в ракурсе проблематики этого разыскания вызывает и сборник статей к 90-летию академика Наталии Юльевны Шведовой Язык как материя смысла (2007), содержащий статью Юрия Степанова Классика и авангард. К юбилею книги Н. Ю. Шведовой (1960) и ее автора сегодня, в которой подчеркивается, что „Н. Ю. своей книгой открыла эпоху в новой русской словесности, «словес- 
ности Авангарда»" (Stepanov 79). Перечень подобных публикаций можно продолжить, но особенности такого типа текстов до сих пор в лингвистике тщательно не изучались, поскольку это сравнительно новый жанр научной литературы.

В Институте русской и украинской филологии также существует добрая традиция посвящать один из выпусков журнала „Studia Rossica Posnaniensia” юбилеям известных ученых, работающих в УАМ. Например, в 2018 году вышел номер в честь юбилея профессора Ежи Калишана, в котором предлагается анализ его лингвофилософской компетентности (см. Kosmeda 2018). Жанр статьи Лингвофилософия Ежи Калишана и его вклад в развитие польской русистики (на материале монографических исследований ученого) представляется гибридным - отражает особенности таких жанров, как научная статья, рецензия, обзор, посвящение.

Профессор Анджей Ситарский в свое время также стал автором статьи в виде гибридного текстового жанра посвящения-поздравления в связи с юбилеем вашей покорной слуги, за что я ему очень признательна, и сейчас понимаю, что в своих пожеланиях Директор Института изящно сформулировал мою перспективу, предвидел длительные годы нашей совместной работы, ср.:

Jako Dyrektor Instytutu Filologii Rosyjskiej UAM w Poznaniu jestem przekonany, że pasja naukowa i organizacyjna Pani Profesor Tetyany Kosmedy, Jej życzliwość i konsekwencja zapiszą się nowymi sukcesami w dziejach ukrainistyki poznańskiej (Sitarski 2012: 17).

Таким образом, жанр этой статьи определяю как эго-текст, воспоминания-посвящения о деятельности известной личности в честь юбилея. Думаю, что этот жанр должен получить развитие на фоне памяти о незаурядной человеческой деятельности, заслуживающей глубокого уважения. Вместе с тем этот жанр должен стать и предметом лингвистического анализа.

\section{Понятие эго-текста и его жанровое разнообразие}

Эго-текст - это, как представляется, текст, основанный на субъективной авторской точке зрения, т. е. текст, создающийся с позиций эгоцентризма. Типичными жанрами эго-текстов, как известно, являются дневник, автобиография, письмо, эпиграмма, афоризм и, конечно, воспоминания (мемуары), поскольку именно в этих речевых жанрах наиболее последовательно отражается языковое сознание автора с его чувствами, эмоциями, интенциями, интимизированными мыслями, надеждами, мечтами, оценками, идио- 
стилевыми особенностями, психотипом, характером и т. д. (см. подробнее: Kosmeda, Zahnitko, Krasnobaieva-Chorna). Эго-текст, как и любой другой текст, - это сложный сгусток смыслов, „текст в тексте” (термин Юрия Лотмана), поскольку в нем соединяется обыденная повседневная разговорная речь с профессиональной, художественной, публицистической, философской, научно-публицистической и т. д., своеобразно проявляется интертекстуальность, феномен прецедентности, аксиологичность, интимизация, репрезентирована разножанровая гибридность. Эго-тексты дают возможность последовательно понять внутренний мир человека, его мировидение, мироощущение и миропонимание, на основании изучения таких текстов можно выяснить и персональную „языковую биографию” каждого конкретного человека (см. подробнее об этом: Kosmeda 2015).

По своему содержанию эго-тексты представляют широкую и разноплановую тематику, они воссоздают персональную когнитивную и, соответственно, индивидуальную языковую картину мира отдельной личности на фоне когнитивной и языковой картин мира определенной эпохи, времени, в котором пребывает рассматриваемая языковая личность - автор персональных текстов. Эго-тексты могут информировать и о мелких жизненных событиях, учитывая обыденные ситуации, факты, но могут представлять и масштабные события, переживаемые этой личностью. Все является одинаково важными, но при этом всегда вербализуется личная (субъективная) оценка повествователя, творца подобных текстов. Однако из отдельных субъективных точек зрения, как известно, и складывается единая, хотя, возможно, и мозаическая картина. Это собственные размышления конкретных лингвоперсон о событиях, фактах, личной судьбе и судьбе государства, нации, человечества, конкретных институций, речь идет о мыслях личности, о ее исканиях, разочарованиях, увлечениях и др. (см. об этом: Veličko). При этом наиболее последовательно актуализируются речевые средства, вербализующие лингвостилистическую категорию интимизации и лингвофилософскую категорию оценки.

В эго-текстах наблюдается попытка понять и себя, и свое окружение по определенным критериям (профессиональная деятельность, гражданская позиция, жизненные установки и под.), в том числе и гендерной, и этнической, и национальной принадлежности человека, учитываются духовные и душевные качества - моральный императив (верность идее, любовь, идеал, совесть, честь и под.).

Функциональная нагрузка эго-текстов велика, поскольку эти тексты не только информируют, отражают субъективные мысли человека, но и аккумулируют индивидуальный опыт, актуализируют память, репрезентируют критику, реализуют функцию корреляции, т. е. взаимодействия отдельной 
личности с другими людьми в обществе. Эти тексты выполняют также такие функции, как эмоциональная, экспрессивная, импрессивная, аппелятивная, культурологическая, аттракционная - происходит лингвализация окружающей действительности и внутреннего мира человека одновременно.

\section{Интерпретация категории памяти, отраженной в эго-текстах воспоминаний}

Своеобразное место в системе эго-текстов, как уже отмечалось, занимают воспоминания, интерпретируемые, прежде всего, как текст, оформленный от первого лица - участника или свидетеля отраженных в нем событий. Во время создания воспоминаний последовательно и выразительно актуализируется категория памяти. В воспоминаниях память выступает в функции собеседника, она актуализируется в фокусе диалога с Alter Ego, „другим Я”, которое нацелено на прошлое (Я-прошлое). Наталья Брагина квалифицирует такой дискурс как „диалог со своей душой” (Bragina 90). Названная исследовательница подчеркивает, что память в этом случае имеет голос и способна разговаривать. Она вступает с человеком в диалог, стремясь повлиять на его взгляды, позицию и при этом она „заверяет”, „переубеждает”, „,советует”, „отвечает на вопросы”, „заставлять сомневаться”. Она и „свидетель”, и „судья”, и „помощник”, память „может вступать в спор с Эго” (см. Bragina 90-93). Н. Брагина подчеркивает, что психофизические свойства памяти в языке передаются при помощи метафор, ,расщепляющих" человеческое „Я’ на двух участников диалога: говорящего и слушающего. Первый представляет прошлое, второй - настоящее. Таким образом, противоречия между настоящим актуальным и прошлым плюсквамперфектным может персонифицироваться и выражаться в языке сквозь связь „Я” человека с его памятью (Bragina 93). Но в случае воспоминаний-посвящений, поздравлений память фокусируется исключительно на положительных моментах жизни, положительных чувствах и эмоциях, достоинствах человека, его достижениях. Такой подход, целеустановка и позволяют создавать уникальные гибридные эго-тексты воспоминаний, в том числе и воспоминания-посвящения.

Память принадлежит к междисциплинарным научным понятиям, поскольку в разных формах она проявляется во всех аспектах человеческой жизни. Она включает в себя не только процессы сохранения индивидуального опыта, но и механизмы трансформации имеющейся информации (см.: Kaźmierska; Tyrowicz). В психологии ее определяют как когнитивный процесс организации, сохранения, восстановления и забывания приобретенного опыта. Память связывает прошлое субъекта с его настоящим и будущим. 
Она выполняет важную познавательную функцию. Личность (ее навыки, привычки, надежды, желания и помыслы) существует благодаря памяти. В процессе психологического анализа памяти важно учитывать, что она входит в целостную структуру личности человека. Зависимо от того, как развивается мотивационная сфера, вызванная потребностями человека, может меняться отношение субъекта к своему прошлому, от этого зависит, как одно и то же знание сохранится в памяти. У памяти выделяют три взаимосвязанных процесса: запоминание, сохранение и воссоздание. По материалам, которые сохраняет память, ее можно разделить на когнитивную, эмоциональную и личностную. По модальности сохраненных образов память бывает словесно-логическая и образная. Уровень развития этих видов памяти, как правило, неодинаков, поэтому можно утверждать, что определенный вид памяти человека может преобладать, что и фиксируется в эго-текстах. Среди характеристик памяти и скорость запоминания, и объем того, что запомнилось, и скорость забывания, длительность сохранения, точность воссоздания событий и под. (см. Golovin).

В процессе подготовки эго-текста воспоминаний очень важной, как представляется, является личностная, эмоциональная память - сохранение в человеческом сознании личностных переживаний и чувств, поскольку впечатлительность и чувственность - предпосылки для становления отдельных коммуникативных качеств. Эмоциональная память - условие наличия сочувствия. Она является основой мастерства представителей некоторых профессий, в частности актеров, учителей, преподавателей. Ее отсутствие тормозит проявление эмоциональности (Golovin). Эмоциональная память, естественно, вербализуется в виде эмоциональных концептов.

Важно еще и то, что по своей природе человек всегда настроен на критическое осмысление действительности, в языковом сознании каждой языковой личности, как и в словарном составе каждого отдельного языка в целом, хранится больше языковых средств, репрезентирующих отрицательную оценку, и люди чаще моделируют отрицательные смыслы в повседневной коммуникативной деятельности, что нашло отражение в одном из основных законов коммуникации - повышенном интересе к отрицательным аспектам жизни каждого отдельного человека и активном обсуждении подобных фактов. Данное явление квалифицируется как асимметричность языка в выражении положительных и отрицательных оценок с преобладанием последних. Хорошее воспринимается человеком как норма, что и фиксируется в языке (см. об этом: Kosmeda 2000). Стало аксиомой сегодня и утверждение, что для моделирования положительной оценки чаще вербализуют прошедшее время, поскольку все, что уже произошло, легче воспринимает человеческая психика. Настоящее и будущее еще не может быть всесторонне оценено. 
Речь идет и о вербализации грамматических категорий, в частности и категории времени (см. Haliman).

Таким образом, очевидно, семантика и прагматика эго-текстов основана на особой потребности актуализировать память, а положительные смыслы и грамматические ресурсы языка ориентированы на прошедшее время. Кроме того, общая тональность эго-текста зависит и от того, каким психотипом обладает языковая личность как автор воспоминаний. Все перечисленное важно не только для процесса написания воспоминаний, но и для их интерпретации, для построения целостной теории эго-текста с учетом многообразной системы жанров.

\section{Профессор Ситарский как объект жанра воспоминания- посвящения}

Профессор Анджей Ситарский - известный ученый, польский русист, лингвист, чья научная деятельность была сфокусирована на проблемах русской грамматики, лингвоконцептологии, лингвоаксиологии, лингвокультурологии, фразеологии, лингвистики текста. Это опытный и успешный преподаватель русского языка, в частности его практического курса, описательной грамматики, дисциплин переводоведческого цикла, блестящий организатор науки и дидактического процесса, умеющий видеть перспективу, воспитывать талантливых ученых, организаторов науки и руководивший Институтом русской филологии УАМ более 10 лет - с 2008-го по 2019-й годы. В жизни и человека, и Института - это, как представляется, целая эпоха.

Считаю большой заслугой Анджея Ситарского перед Институтом - подготовку талантливых учеников. Профессор воспитал четырех докторов наук - перспективных молодых ученых: это Лукаш Малецкий (2012), Дария Слупянек-Тайнер (2015), Конрад Рахут (2018), Марианна Плакуева-Олейничак (2019). Для своих докторантов ученый нашел именно ту проблему, которая была по душе каждому из них, смогла заинтересовать, поглотить и привести к положительным результатам ${ }^{1}$. Каждая проблема отражает, собственно, научные увлечения и самого научного руководителя.

${ }^{1}$ Łukasz Małecki, Когнитивная семантика концепта СТРАХ (на материале современной русской и украинской прессы) (2012); Daria Słupianek-Tajnert, Когнитивныий анализ глаголов зрительной периепщии в русском и польском языках (2015); Konrad Rachut, Postaci dyskursu w perspektywie tworzenia i tlumaczenia „, poetonimów”. Na podstawie polskiego i rosyjskiego przekładu sagi o Harrym Potterze (2018); Marianna Plakueva-Olejniczak, Strategie przektadu jako wypadkowa interakcja czynników świadomego wyboru tłumacza. Na przykładzie polskich tłumaczeń wczesnej poezi Borysa Pasternaka (2019). 
Мне посчастливилось проследить особенности формирования и развития одного из учеников профессора Ситарского - лучшего нынешнего организатора учебного процесса в Институте, обладателя студенческих симпатий на протяжении последних лет, активного молодого ученого, талантливого преподавателя и организатора науки Лукаша Малецкого. Этот преподаватель работал на Кафедре украинистики (2011-2019) как мой коллега, поэтому мне удалось всесторонне познать эту личность. Меня поразило стремление молодого человека больше знать, много работать, всегда самостоятельно „докапываться” до истины, выступать с интересной инициативой, быть точным и пунктуальным в работе, предельно внимательным к окружающим, корректным. Я оппонировала докторскую диссертацию Лукаша Малецкого и была поражена его научной смелостью, скрупулезностью, убедительностью, а также новизной и методологическим совершенством его докторского разыскания, высоким уровнем профессиональной подготовки, его языковой компетентностью с учетом не только родного польского, но русского и украинского языков, его коммуникативной и культурологической компетентностью в проекции на названные выше лингвокультуры. Считаю, что профессор Ситарский „разглядел” многоаспектный талант своего ученика: и как талантливого лингвиста, и как блестящего преподавателя русского и украинского языков, и как великолепного организатора учебной и научной работы, и просто как порядочного, надежного человека. Назначить его заместителем директора по учебной работе было очень правильным решением (2016). С этой работой Лукаш Малецкий блестяще справился, справедливо заслужив любовь и уважение. Не ошибся Директор Института, предложив Лукашу Малецкому выполнять обязанности секретаря журнала „Studia Ukrainica Posnaniensia”, который был основан при моей помощи. Наш тандем (меня как главного и научного редактора и его как секретаря журнала) был, как представляется, очень гармоничен. Именно при активной его работе этот журнал получил популярность в научных кругах и высокий статус, т. к. был введен в солидные наукометрические базы. Секретарь приобрел высокий пиетет у авторов журнала из-за тщательной и системной переписки по поводу технических проблем оформления публикаций, выхода журнала в свет, его рассылки и т. д., благодаря его изысканной корректности и любезности. Кроме этого, длительные годы (2012-2020) Лукаш Малецкий выполнял обязанности секретаря Международной научной конференции „Украинистика: вчера, сегодня, завтра...”, организованной при моем участии Кафедрой украинистики по рекомендации и при поддержке профессора Ситарского как директора Института (с 2011 года) (см. фотография 1). 


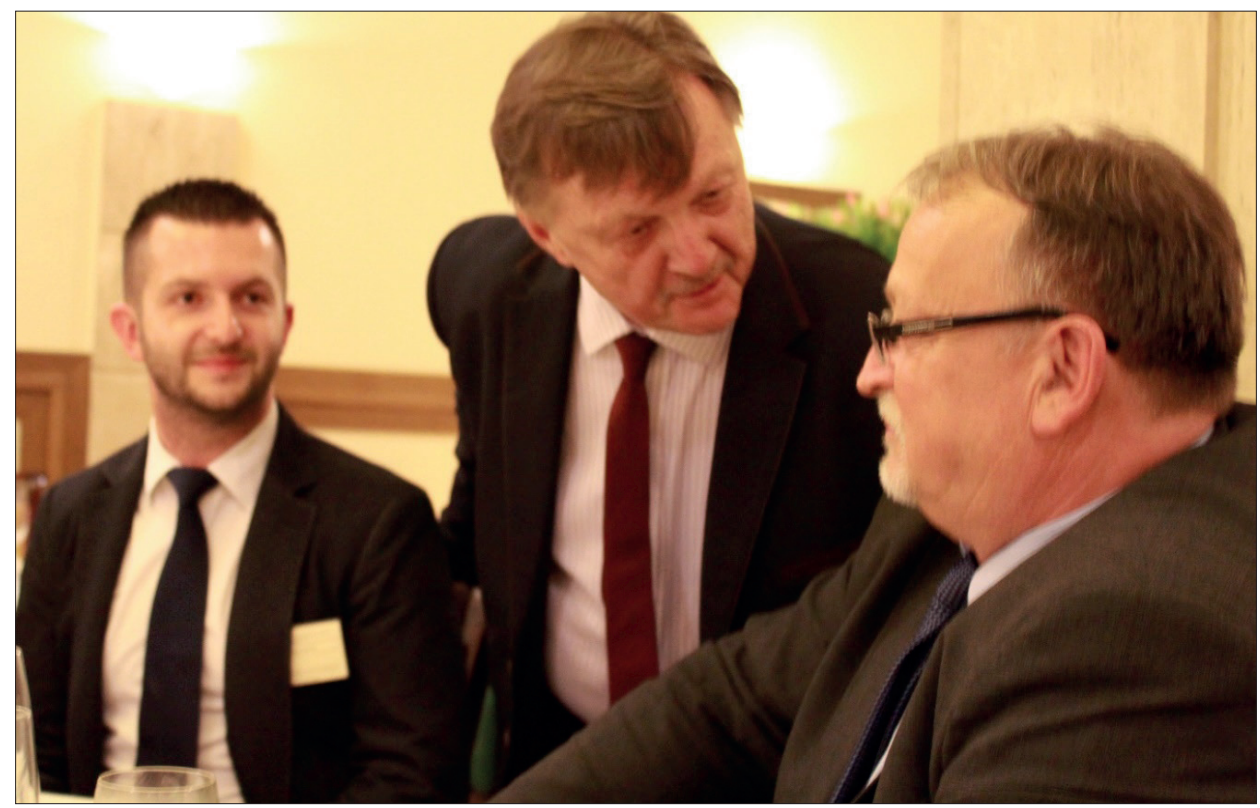

Фотография 1. Во время проведения Первой международной конференции (первично семинара) „Украинистика: вчера, сегодня, завтра...” (2011). Слева направо - д-р Лукаш Малецкий, профессор Анджей Ситарский, д-р Войцех Куминский (автор Татьяна Осипова)

Мне посчастливилось читать письма благодарности, которые присылали Лукашу Малецкому участники конференций. Здесь и восторг, и восхищение, и удивление, и добрые пожелания. Поэтому могу заявить со всей ответственностью, что, если бы профессор Ситарский воспитал только лишь одного Лукаша Малецкого, уже исключительно за это он мог бы войти в Золотую книгу летописи Института. Ибо каждый ученый находит продолжение в своих учениках (см. фотография 2).

То же самое можно сказать и о Конраде Рахуте, который блестяще справляется с функциями секретаря журнала „Studia Rossica Posnaniensia” и является автором новаторской диссертационной работы, посвященной поэтонимам, функционирующим в произведениях о Гарри Поттере. Ученый глубоко и всесторонне рассмотрел специфику перевода собственных имен, функционирующих в художественном дискурсе Джоан Роулинг и переводах ее текстов на русский и польский языки. Научное разыскание выполнено в междисциплинарном ключе и на материале нескольких языков, что позволило автору сделать убедительные выводы и даже расширить теорию литературной ономастики, благодаря предложению в польскую ономастику новые термины. Считаю, что научный потенциал этого молодого ученого также чрезвычайно высок, о чем свидетельствовал весь процесс защиты, 


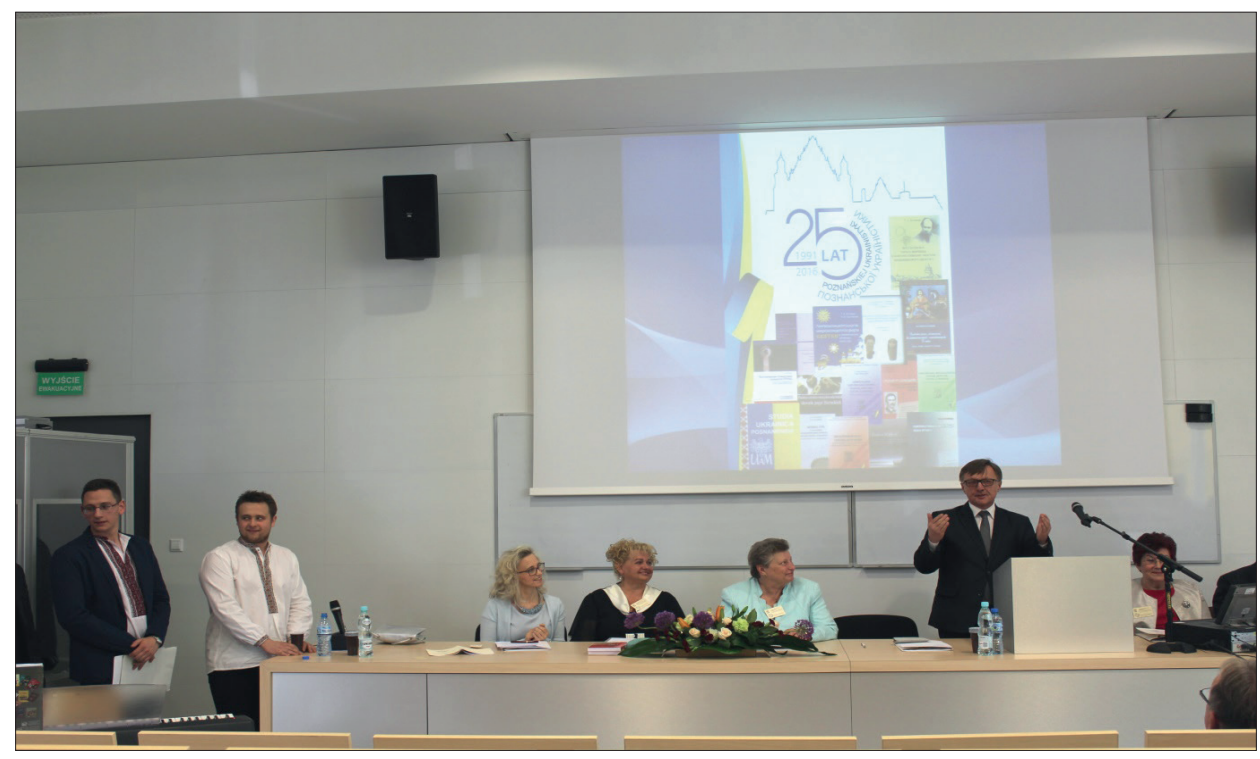

Фотография 2. Директор Института профессор Анджей Ситарский открывает конференцию посвященную 25-летию Кафедры украинистики (2016) (автор Татьяна Осипова)

который был очень ярким, ибо разгорелась активная дискуссия, поэтому он и запомнился во всех подробностях (2018).

В свою очередь, диссертационное исследование Дарии Ступянек-Тайнерт Когнитивный анализ глаголов зрительной перцепции в русском и польском языках (2015) вдохновило меня к написанию нескольких статей, в которых я цитирую отдельные фрагменты работы этой блестящей исследовательницы, сумевшей впервые заметить и тщательно описать важные лингвокультурные константы языковой личности русского человека, наглядно подтвердив свой вывод языковыми фактами, и доказав, что в русском национальном характере выразительно прослеживается желание все контролировать. Этот характерный признак ментальности носителей русского языка активно вербализуется, что, в частности, проявляется и в специфике использования глаголов зрительной деятельности. Мои личные беседы с названной молодой ученой свидетельствуют о том, что Дария Ступянек-Тайнерт, как и все остальные ученики профессора Ситарского, обладает очень высоким научным потенциалом.

Организаторская деятельность профессора Ситарского частично рассмотрена в отдельных публикациях (см., например: Markunas; Pacholczyk). Очевидно, можно с уверенностью утверждать, что перед нами маститый ученый, которого охотно приглашают на всевозможные заседания различных комиссий, редколлегий, ученых советов и т. д. Подобные ученые наиболее 
влиятельны именно в организационном отношении. Они большие эрудиты и интеллектуалы.

Однако в этой статье хотелось бы осветить вопрос о той поддержке, какую предоставил профессор Ситарский познанской украинистике. Ибо с его именем ассоциируется процесс ее создания, становления и развития. Во время руководящей деятельности профессора Ситарского Институт был переименован в Институт русской и украинской филологии (2016), что удалось сделать не сразу, т. к. на Совете Института по этому поводу голосование проходило дважды. Первый раз (2015) большинство не осознало необходимости такого переименования, и во время тайного голосования предложение профессора Ситарского не было поддержано. Однако Профессор не отказался от своей идеи и намерения. Вскоре были найдены убедительные факты и аргументы, и предложение профессора Ситарского было поддержано, что позволило, как представляется, создать уникальную структуру в УАМ, ибо на сегодняшний день ни в одном из польских вузов нет подразделения с таким названием и таким содержанием, такого Института нет ни в одной стране Восточной Европы. Профессор Ситарский способствовал не только становлению украинистики в Институте, но и ее стремительному развитию во всех аспектах деятельности вузовской кафедры. Это, во-первых, формирование мощного кадрового потенциала на базе собственного ресурса, т. е. выпускников Института (Лукаш Малецкий, Рышард Купидура, Доминика Янчура) и приглашенных молодых людей из Украины (Марта Абузарова [Стецула], Олена Ковалевская [Гоменюк]), т. е. планирование и реализация процесса подготовки докторантов, в частности и по специальностям „украинский язык” и „украинская литература”; кроме этого, стимулирование профессионального роста уникальных преподавателей-методистов с большим опытом работы - это д-р Мария Четырба; во-вторых, содействие в подготовке и издании ряда учебников, учебных пособий и словарей по украинскому языку для польских студентов, в-третьих, активизация научной работы - поддержка инициативы по организации и проведению международных семинаров и конференций, в частности периодической конференции „Украинистика: вчера, сегодня, завтра...”, а также содействие по созданию периодического печатного рецензируемого научного журнала „Studia Ukrainica Posnaniensia” (2013), о чем частично уже шла речь. Однако подчеркнем, что данный журнал также стал уникальным, поскольку это единственное периодическое издание в Польше и, как представляется, в Восточной Европе, освещающее исключительно проблематику украинистики с учетом широкой системы вопросов, связанных с актуальными направлениями украинской лингвистики, литературоведения, методики преподавания украинского языка и переводоведения. Этому журналу удалось „выстоять” в суровых условиях конкурен- 
ции и получить определенный статус во время оценки компетентной Комиссии Министерства науки и образования Польши (2019).

Уместно здесь отметить, что профессор Ситарский - человек слова и дела, умеющий видеть перспективу и успешно ее воплощать в жизнь, ведь все нынешние достижения познанской украинистики (и открытие новых специализаций по направлениям: 1), „украинская филология”2 на уровне бакалавриата и на уровне магистратуры, 2) ,украинская филология с филологией английской” в современных дидактических и научных формах) Директор Института в далеком 2011 году предвидел, спланировал, описав в публикации Zamierzenia perspektywiczne Filologii Ukraińskiej na Uniwersytecie im. Adama Mickiewicza w Poznaniu (Sitarski 2011).

Профессор Ситарский не только уникальный организатор науки, но и оригинальная языковая личность. За годы общения с лингвистом в различных коммуникативных ситуациях, в частности во время слушания его научных докладов на конференциях разного уровня, а также присутствуя на выступлениях во время рабочих совещаний, заседаний Совета Института, в личных беседах, мне, как представляется, удалось зафиксировать в памяти основные черты стиля его общения.

Могу с уверенностью констатировать, что Анджей Ситарский представляет собой билингва, который в одинаковой мере совершенно владеет и польским (родным) языком, и языком своей профессии - русским. Его языковую компетентность в отношении русского языка не только я, но и коллеги, с ним общающиеся, оценивают очень высоко, отмечая ее нормативность на всех уровнях языковой системы. Вспоминаю высокую оценку, данную речи Ситарского, одним из профессоров-русистов Львовского национального университета имени Ивана Франко, с которым Профессор общался всего лишь несколько минут по телефону. Была отмечена удивительно чистая и правильная русская речь.

Коммуникативная компетентность Профессора также отличается высоким уровнем, поскольку ученый в совершенстве владеет и жанровой компетентностью русской лингвокультуры, стратегиями и тактиками моделирования коммуникативных актов. Идиостиль Анджея Ситарского отличается частотностью употребления фразеологических единиц, прецедентных выражений, умением моделировать юмор, иногда иронию. Коммуникативную тональность ученого можно охарактеризовать, как доброжелательную, оптимистическую, наблюдается желание понять собеседника, расположить его к себе, оказать помощь.

2 До 2012 года в Институте русской филологии существовала лишь специальность „русская и украинская филология" на уровне бакалавриата. 
В моей памяти сохранились так называемые вызовы „на ковер”. Отмечу, что в этих случаях господин Директор чаще со мной общался на русском языке. Я чувствовала, что руководитель Института тщательно продумывал тактику разговора, чтобы избежать недоразумений, начинал с упоминаний о моих достоинствах, достижениях, а потом плавно переходил к замечаниям, отмечая, что я, очевидно, не совсем знакома с правилами польских учебных учреждений, ибо такой-то вопрос желательно было решить несколько иначе. Речевые жанры замечания и порицания в „исполнении” Руководителя Института всегда сопровождались шутками, прибаутками, юмором и были изысканно корректны.

Не могу сказать, что наши беседы - образцы идеального общения. Конечно, возникали споры, однако, справедливости ради, подчеркну и то, что Директор умел признать свою ошибку, заблуждение, его можно было переубедить, приведя необходимые аргументы. Иногда Профессор заявлял, что, хотя отдельные вопросы мы по-разному понимаем, однако это хорошо, т. к. истина рождается в споре, а прогресс основан на борьбе противоположностей. Практически всегда мы находили консенсус, а это, как известно, достигается определенными усилиями участников коммуникации.

Одна из основных функций невербальной коммуникации - выражать чувства и эмоции с помощью внешнего поведения (движения тела, жесты, голосовые модификации и под.), поскольку паравербальные и невербальные сигналы свидетельствуют, главным образом, о состоянии человека. Кроме того, сопровождая вербальную речь, „невербалика” выполняет и экспрессивную, и эмоциональную функции. Обычно положительные эмоции выражаются открыто, а отрицательные - наоборот, скрыто, поскольку человек пытается их контролировать. Если попробовать очертить невербальный портрет профессора Ситарского, то вспоминается его живость во время общения, что отражается во внимательном и наблюдательном взгляде, активной мимике лица, доброжелательной улыбке, движениях рук и тела, свидетельствующих о положительном отношении к собеседнику.

Наиболее яркая черта языковой личности Ученого - его эмоциональность, которая проявляется во всей его вербальной и невербальной речевой деятельности. Отмечу и выраженный психотип Анджея Ситарского как экстраверта. Он больше любит говорить, нежели слушать, речь довольно быстрая, образная и яркая, с выраженными эмоциональными всплесками, усеянная индивидуальными метафорами и другими орнаментальными средствами. Его чувства легко прочитываются, они всегда „написаны” на лице. Очень эмоциональными были выступления Директора на мероприятиях, которые проводила Кафедра украинистики (ежегодные Шевченковские дни, имеющие разнообразные формы, ставшие доброй традицией Конкурсы украинской поэзии и др.). 
В этих случаях Профессор находил изысканные слова благодарности, обращаясь к каждому участнику мероприятия как бы индивидуально, будь то студент или профессор. Особенно умиляла Профессора украинская песня и в исполнении профессионалов, и звучавшая из уст студентов. Вообще, Анджей Ситарский - большой ценитель и любитель искусства. Он всячески поощрял студенческое творчество - и стихотворное, и музыкальное, и изобразительное. Безусловно, ценил и креативную научную работу студентов, выступающих на научных студенческих чтениях с фрагментами своих бакалаврских и магистерских разысканий. За все это я очень благодарна Руководителю Института, с которым имела честь работать много лет.

\section{Выводы}

Таким образом, в пределах данного эго-текста, определенного как жанр воспоминания-посвящения, активизируя диалог со своей памятью, спроецированный на временное пространство (2011-2020) моей работы в качестве руководителя Кафедры украинистики в УАМ, хочу отметить высокую продуктивность и эффективность деятельности Руководителя Института, в частности относительно развития украинистики как учебного и научного направления, Его инициативность, энергичность, активность, талант видения перспективы, умение подбирать и воспитывать кадры, в том числе и своих учеников, воспитывать их для успешной деятельности на благо Института.

Профессора Ситарского можно квалифицировать как настоящего профессионала, элитарную изысканную русскоязычную лингвоперсону с высоким уровнем всех видов компетентностей (языковой, речевой, жанровой, культурологической), обладающей психотипом экстраверта, с уникальными индивидуальными чертами, выражающимися во всех видах его вербальной и невербальной организаторской, педагогической и научной коммуникативной деятельности.

\section{Библиография}

Bragina, Natal'â Georgievna. Pamât'v âzyke i kul'ture. Moskva, Âzyki slavânskoj pis'mennosti, 2007.

Golovin, Sergej Ûr'evič. Slovar'praktičeskogo psihologa. Minsk, Harvest, 1998. Web. 19.08.2018. http://www.klex.ru/1ql.

Halìman, Oksana Volodimirìnna. Gramatika ocìnki: morfologični kategorï ukraïns'koï movi. Harkìv, Majdan, 2019. 
Kosmeda, Tetâna. Aksiologični aspekti pragmalìngvistiki: formuvannâ ì rozvitok kategorï ocìnki. L'vìv, LNU ìm. İvana Franka, 2000.

Kosmeda, Tat'âna. „Lingvofilosofiâ Eži Kaliŝana i ego vklad v razvitie pol'skoj rusistiki (na materiale monografičeskih issledovanij učenogo)". Studia Rossica Posnaniensia, 45, 2018, s. $143-154$.

Kosmeda, Tetâna Anatolï̈nna. „Egò-teksti Stepana Rudans'kogo: vìdtvorennâ komunìkativnoï kompetenciï ta faktìv jogo „movnoï bìografiił”. Stepan Rudans'kij: fenomen modelûvannâ „živogo” movlennâ ukraïncìv. Red. Tetâna Anatolï̀nna Kosmeda, Tetâna Fedorìvna Osìpova, Nataliâ Vìtalïivna Pìddubna. Harkìv-Poznan', Kolo, 2015, s. 189-205.

Kosmeda, Tetyana, Anatolij Zahnitko, Zhanna Krasnobaieva-Chorna. Delineation of Linguopersonology and Linguoaxiology. Poznań, Wydawnictwo Naukowe UAM, 2019.

Krylov, Sergej Aleksandrovič, „O naučnom tvorčestve N. D. Arutûnovoj”. Sokrovennye smysly: Slovo. Tekst. Kul'tura. Sbornik statej v čest' N. D. Arutûnovoj. Red. Ûrij D. Apresân. Moskva, Âzyki slavânskoj kul'tury, 2004, s. 837-845.

Markunas, Antoni. „Początki i teraźniejszość filologii rosyjskiej na UAM”. Scripta Neophilologica Posnaniensia, 8, 2006, s. 313-323.

Pacholczyk, Tadeusz. „Złoty Jubileusz Rusycystyki Poznańskiej - problematyka badawcza międzynarodowych konferencji naukowych (1989-2012)”. Przegląd Rusycystyczny, 1 (149), 2015, s. 135-140.

Sitarski, Andrzej. „Z człowiekiem w sercu. O Pani Profesor Tatianie Kosmedzie w związku z Jubileuszem”. Kosmeda Tetâna Anatolï̈nna. Biobibliografičnij pokažčik. Red. İrina Kočan, Anna Gornâtko Šumilovič. Drogobič, Kolo, 2012, s. 16-17.

Sitarski, Andrzej. „Zamierzenia perspektywiczne Filologii Ukraińskiej na Uniwersytecie im. Adama Mickiewicza w Poznaniu”. Zakład Ukrainistyki: Perspektywy, teraźniejszość, przeszłość (z okazji 20-lecia istnienia): opracowanie naukowe. Red. Andrzej Sitarski, Tetiana Kosmeda. Poznań, Instytut Filologii Rosyjskiej UAM, 2011, s. 7-9.

Stepanov, Ûrij Sergeevič. „Klassika i avangard. K ûbileû Knigi N. Û. Švedovoj (1960) i ee avtora segodnâ”. Âzyk kak materiâ smysla: sbornik statej k 90-letiû akademika N. Û. Švedovoj. Red. Maja V. Lâpon. Moskva, Izdatel'skij centr „Azbukovnik”, 2007, s. 79-84.

Tyrowicz, Marian. W poszukiwaniu siebie. Wspomnienia i refleksje. T. 1: Pod lwowskim niebem. Lublin, Wydawnictwo Lubelskie, 1988.

Uspenskij, Vladimir Andreevič. „Tat'âna Mihajlovna Nikolaeva kak sobesednik”. Azzyk. Ličnost'. Tekst: sbornik statej k 70-letiû T. M. Nikolaevoj. Red. Vladimir Nikolaevič Toporov. Moskva, Âzyki slavânskih kul'tur, 2005, s. 953-958.

Veličko, Natal'â Valentinovna. „Samonominacii i samoharakteristiki v Pis'mah A. P. Čehova âltinskogo perioda (sentâbr' 1898 - aprel'1899 g.)'. Učenye zapiski Tavričeskogo nacional 'nogo universiteta im. V. I. Vernadskogo. Seriâ Filologiâ, 20 (59), 2007, s. 420-424. 